\title{
Charity: A health volunteer success story
}

\author{
Amy Dempsey \\ Population Council
}

Follow this and additional works at: https://knowledgecommons.popcouncil.org/departments_sbsr-rh

Part of the Demography, Population, and Ecology Commons, Family, Life Course, and Society Commons, International Public Health Commons, and the Maternal and Child Health Commons How does access to this work benefit you? Let us know!

\section{Recommended Citation}

Dempsey, Amy. 2017. "Charity: A health volunteer success story," Ending Eclampsia Country Brief. Washington, DC: Population Council. 


\section{ENDING
Eclampsia}

\section{NIGERIA}
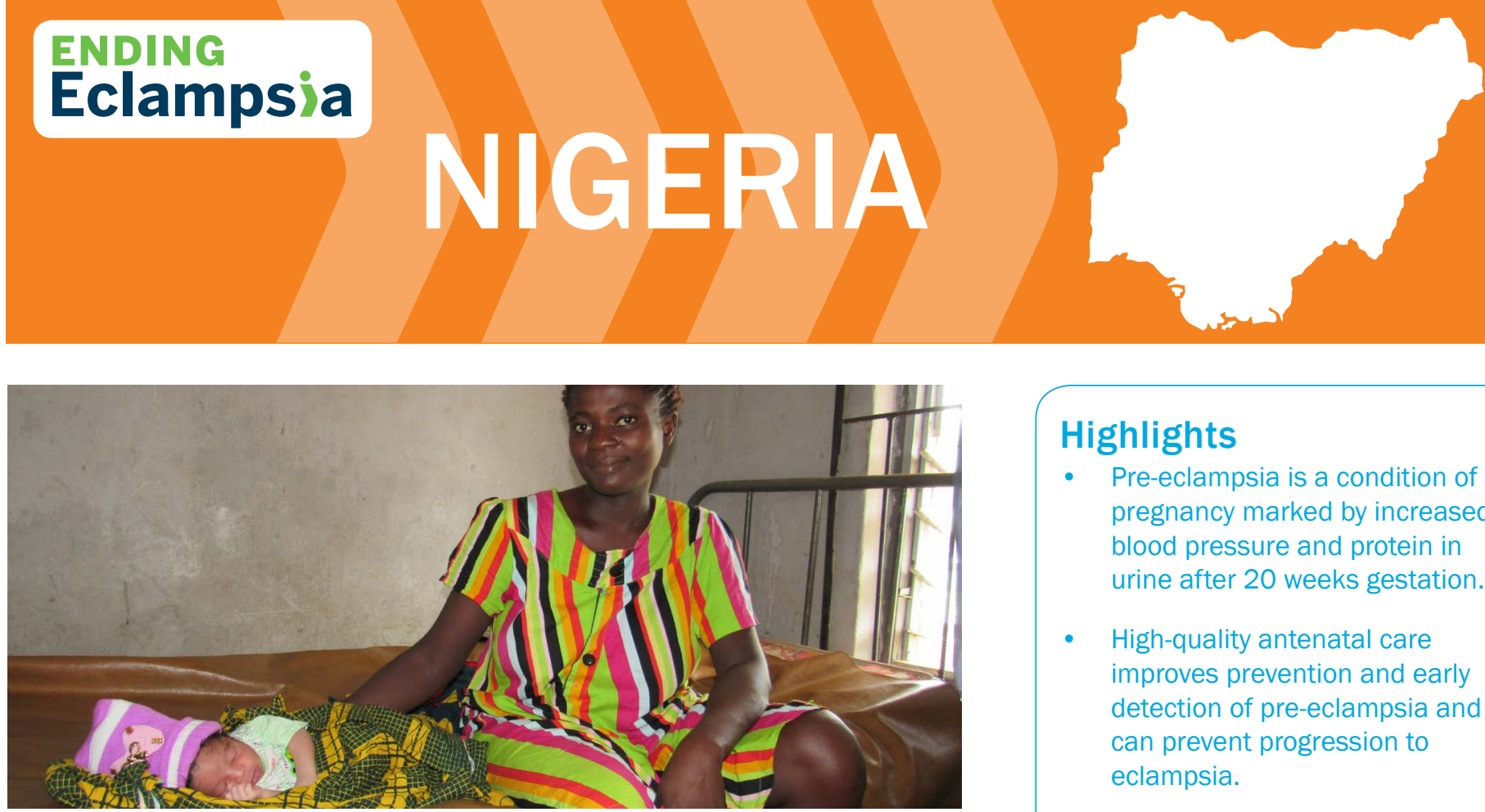

Photo credit: Karen R. Kirk, Population Council

\section{Charity: A health volunteer success story}

Charity Ochale, a Community Health Extension Worker (CHEW) in Nigeria's Ebonyi State, had never heard of pre-eclampsia, a hypertensive disorder of pregnancy and the country's leading cause of maternal mortality. If undetected and untreated, pre-eclampsia can progress to eclampsia and cause convulsions, which can kill a mother and her baby. Despite contributing to 23 percent of Nigeria's maternal mortality, Charity was not the only $\mathrm{CHEW}$ without any knowledge of pre-eclampsia and eclampsia (PE/E).

As a CHEW, Charity's job is to support families by creating linkages between them and primary health services. These services can sometimes lead to lifesaving care, especially when related to PE/E. In October 2016, Charity attended an Ending Eclampsia-led training with 50 other CHEWs. The training's objective was to teach them how antenatal care (ANC) providers can prevent pregnancy-related complications like PE/E.

Results from Ending Eclampsia's landscape analysis of seven states in Nigeria served as the catalyst for the training. Researchers conducted observations of client-provider interactions during ANC visits. They assessed health care providers' knowledge of proven risk factors for pre-eclampsia, including chronic hypertension, previous history of PE/E, obesity, pre-existing diabetes or diabetes in pregnancy, advanced maternal age ( $\geq 35$ years), sickle cell diseases, and connective tissue diseases.

The Ending Eclampsia project seeks to expand access to proven, underutilized interventions and commodities for the prevention, early detection, and treatment of pre-eclampsia and eclampsia and strengthen global partnerships.

\section{Highlights}

- Pre-eclampsia is a condition of pregnancy marked by increased blood pressure and protein in urine after 20 weeks gestation.

- High-quality antenatal care improves prevention and early detection of pre-eclampsia and can prevent progression to eclampsia.

- Eclampsia is a life-threatening condition characterized by convulsions in women with PE.

- Women in developing countries are 300 times more likely to die from eclampsia than women in developed countries.

- It can be managed by administering antihypertensive drugs and magnesium sulphate (MgSo4).

- MgSO4 is the safest and most effective treatment for severe pre-eclampsia and eclampsia, and is one of the 13 UN LifeSacing Commodities for Women and Children.

- $\quad$ PE/E and other hypertensive disorders in pregnancy increase the risk of pre-term births, which can lead to low birth weight, anemia, and stunting.

\section{USAID}

Made possible by the generous support of the American people through the United States

Agency for International Development (USAID).
The Population Council conducts research and delivers solutions that improve lives around the world. Big ideas supported by evidence: It's our model for global change. popcouncil.org

(C) 2017 The Population Council, Inc
POPULATION COUNCIL

Ideas. Evidence. Impact. 
The observations revealed that primary facility providers do not assess women for these risks and they do not know signs and symptoms associated with PE/E. For more information, see Figure 1.

FIGURE 1. Provider Knowledge of PE/E Risk Factors, Symptoms, and Detection Measures

\begin{tabular}{lcc}
\hline & $(\mathbf{n = 3 7 9 )}$ & \\
\hline & Ebonyi (\%) & National (\%) \\
\hline $\begin{array}{l}\text { Assessed } \\
\text { for PE/E } \\
\text { risk factors }\end{array}$ & 30 & 15 \\
$\begin{array}{l}\text { Detected } \\
\text { PE/E }\end{array}$ & 50 & 53 \\
$\begin{array}{l}\text { Advised } \\
\text { on PE/E } \\
\text { sumptoms }\end{array}$ & 30 & 11 \\
\hline
\end{tabular}

\section{Empowering CHEWs}

During the training, Charity and her colleagues learned the importance of PE/E detection measures, including testing blood pressure (BP) and urinalysis to monitor the amount of protein in urine, as well as glucose measurement for gestational diabetes.

At the training, the CHEWs also learned how to support women preparing for childbirth. For example, prior to going into labor, pregnant women should know their expected date of delivery; the position, the lie, and the presentation of the fetus; and the location of the placenta.

\section{"I knew nothing about PE/E or quality antenatal care before the training, this was my first time hearing about it. Now that I have completed the training, I have had conversations with 10 pregnant women about what they should expect from their providers."}

\section{-Charity, CHEW}

The empowerment that the CHEWs now feel was the most vital piece of the training. Now they can encourage expectant mothers to ask ANC providers about their pregnancy and childbirth, and request specific $\mathrm{PE} / \mathrm{E}$-related detection and prevention services.

\section{Ending Eclampsia in Ebonyi State}

Ebonyi State is one of three states in Nigeria, where the Ending Eclampsia project provides similar trainings, mentoring, and supportive supervision focused specifically on $\mathrm{PE} / \mathrm{E}$ detection, prevention, and treatment measures.

Representing the Ministry of Health as the state's Safe Motherhood Coordinator (SMC), Mary Jane Nwobodo's mandate is to ensure babies born in Ebonyi and mothers are safe from pregnancy-related complications. Her role is to build health providers' capacity to support pregnant women during ANC visits, in labor, and during the postnatal period.

If there are gaps in providers' skills sets, it is Mary Jane's job to work with partners like Ending Eclampsia, UNICEF, and UNFPA to bring them up to standard by providing supportive supervision and on-the-job trainings that span a range of potential maternal health complications, including management and treatment of PE/E and using non-pneumatic anti-shock garments to prevent hemorrhage.

"The Ending Eclampsia project is doing this in an elaborate, effective way because devoting one hour to any issue is not enough. Ending Eclampsia is training providers for two or three days at a time to make sure that every provider knows what they need to know about pre-eclampsia and eclampsia."

-Mary Jane, SMC

\section{CONTACT}

Salisu Ishaku

sishaku@popcouncil.org

Lead Researcher, Ending Eclampsia Nigeria

Population Council, Abuja, Nigeria

Gloria Adoyi

gadoyi@popcouncil.org

Project Coordinator, Ending Eclampsia Nigeria

Population Council, Abuja, Nigeria 